ILA الجمعية المصرية للقر اءة والمعرفة عضو الجمعية الدولية للمعرفة

Faculty of Arts

Department of History

Damietta University

Search title:

\title{
The goddess Hathor in Sinai
}

Literature search for publication, Greek and Roman history major

by the student: Ahmed Abdel Moneim Riad Al-Hakim

\section{Supervised by}

Dr. alhussien ibrahem aboelatta

2021. 
ILA الجمعية المصرية للقر اعة والمعرفة عضو الجمعية الدولية للمعرفة

- 64 - 


\section{الجمعية المصرية للقر اعة والمعرفة عضو الجمعية الدولية للمعرفة}

\section{The Goddess Hathor in Sinai}

Ancient Egyptians sent mineral missions to Serabit El-Khadim (that lies in the North of Al-Maghara Valley in Sinai), where lies the richest semi precious stone Turquoise mines. Egyptians used to call this area, since the oldest ages and till the beginning of the New Kingdom, "Mefakat" i.e., that means the land of the Turquoise . In fact, they called it so because they were excavating from it the stone that was used in the making of the ornaments and amulets that had religious significance ${ }^{(1)}$.

This mineral activity resulted in establishing a temple for worshiping goddess "Hathor", that the Egyptians considered the protective goddess for Serabit El-Khadim - the area in which Turquoise is concentrated. They also used to call her "Nabt Mefakat" i.e., the lady of the Turquoise, and she was figured, most of the times, in the shape of a woman, and in other times, it took the shape of a cow ${ }^{(2)}$.

It is preponderant that the first place that the Egyptians used as a temple for goddess "Hathor" was likely one of the caves in the area. It seems that the Semitic inhabitants of this area were worshiping in this cave a goddess of their own; this was the Semitic goddess "Ashtarot"(3).

Because of the big similarity between the two goddesses, - 65 - 


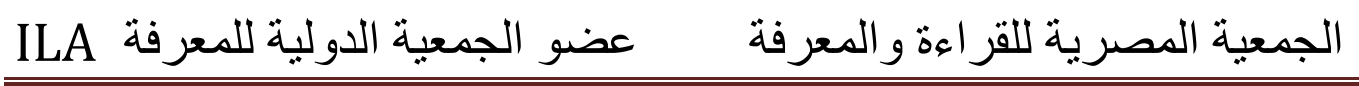

Egyptians started to worship "Ashtarot" in the shape of "Hathor", and the Semitics did the same when they worshiped "Hathor" in the shape of "Ashtarot". This is clear in the fact that the Egyptians called "Ashtarot" "Annah" i.e. the wife of the husband "Ball" and her name is Baalla or Ba-alat, something that means the goddess or the lady i.e. the lady of the Turquoise that won a wide popularity ${ }^{(4)}$.

It is clear from what has been previously discussed that there were two worshipping practiced in the middle of Sinai in the area called Serabit El Khadim one of which was pharaonic Egyptian and the other was Semitic.

There were found some pictures for the goddess "Hathor" in the area of Serabit El-Khadim in the shape of a cow and beside it was the drawing of two ears ${ }^{(5)}$ as a symbol for the goddess's listening to the people's inquiries, those people who went to her to uncover the unknown and to know the places where the Turquoise stone was found in the area ${ }^{(6)}$. Egyptians made for this cow some statues that were made of, or just covered with gold ${ }^{(7)}$. "This leads us to believe that these descriptions are the same of these found in the Holy Koran about the story of the Israeli's cow. The story tells of events that supposedly happened in Sinai before the exit journey of the Israeli people form Egypt to Palestine. This reveals some of the first secrets that surrounded the beginning of religion formation for the Israeli 


\section{الجمعية المصرية للقر اعة والمعرفة عضو الجمعية الدولية للمعرفة ILA}

people. For the importance of this story, the longest chapter in the Holy Koran was named "The Cow". The events are mentioned in the following verses:

And (remember) when Musa (Moses) said to his people: "Verily, Allah commands you that you slaughter a cow." They said, "Do you make fun of us?" He said, "I take Allah's Refuge form being among Al-Jahilun (the ignorant or the foolish). They said, "Call upon your Lord for us that He may make plain to us what it is!" He said, "He says, "Verily, it is a cow neither too old nor too young, but it is) between the two conditions', so do what you are commanded. They said, "Call upon your Lord for us to make plain to us its colour." He said, "He says, "It is a yellow cow, bright in its colour, pleasing the beholders. They said, "Call upon your Lord for us to make plain to us what it is. Verily, to us all cows are alike. And surely, if Allah wills, we will be guided. He [Musa (Moses)] said, "He says, it is a cow neither trained to till the soil nor water the fields, sound, having no other colour except bright yellow." They said, "Now you have brought the truth." So they slaughtered it though they were near to not doing it. And (remember) when you killed a man and fell into dispute among yourselves as to the crime. But Allah brought forth that which you were hiding. So We said: "Strike him (the dead man) with a piece of it (the cow)." "Thus 


\section{الجمعية المصرية للقر اعة و المعرفة عضو الجمعية الدولية للمعرفة ILA}

Allah brings the dead to life and shows you His Ayat (proofs, evidences, verses, lessons, signs, revelations, etc.) so that you may understand". (The Cow 67-73)

There is a semi agreement among interpreters concerning these verses on the occurrence of an unknown murder in the age of Moses, peace be upon him. At that time, the Israeli people asked Moses to ask his God to tell them who the murderer was. Here, Moses told them that God had ordered them to slaughter a cow; something that surprised them because there did not appear to them any relation between slaughtering a cow and knowing the murderer. They thought that Moses was mocking them, but Moses clarified saying that this was what God asked for in order to reveal the truth of the murder. They then started to ask him about the age, the color, and the job of the cow that should be slaughtered. When he explained all this as God inspired to him, they searched till they found a cow in which are satisfied all the qualities, and they slaughtered it. God then reveals to Moses that they should hit the corpse of the murdered man with a piece of this cow, and they did. God brought the dead to life till he mentioned the name of murderer and He took his life again. This was a miracle for Moses on one hand, and a material demonstration on God's ability to bring the dead to life on the other. For this reason, God ends this story saying: "Thus Allah brings the 


\section{الجمعية المصرية للقر اعة و المعرفة عضو الجمعية الدولية للمعرفة ILA}

dead to life and shows you His Ayat (proofs, evidences, verses, lessons, signs, revelations, etc.) so that you may understand".

Aly Abd-el-Wahed emphasizes that the features of the cow God mentions in the miracle accord in general with those mentioned by the Old Testament (Al-Tathniya Book ) in the division procedures ${ }^{(8)}$. It seems that this worshipping was common in Egypt. The Greek historian "Plutarchus" mentions that every province in Egypt used to have its own sacred animal regardless of being worshipped in another province or not ${ }^{(9)}$. These animals were symbols for gods that were distinguished by their names, shapes and feasts. The inhabitants of each province considered the animal that they worship greater than the other animals worshipped in the other provinces. It did not stop at this point, but they also prohibited and banned slaughtering some animals except in their sacred feasts. However, there was at least one worshipping that comprised all the Egyptian people; that was the worshipping of goddess "Isis" and her divine family. "Isis" was worshipped in all the provinces ${ }^{(10)}$, she imposed herself on all different strata and succeeded in drawing them all. The Egyptians depended on agriculture as a main source for food, and "Isis", "Osiris", and their son "Horus" became their most preferable gods.

Greek historian "Herodotus" mentions that the Egyptians made 


\section{الجمعية المصرية للقر اعة والمعرفة عضو الجمعية الدولية للمعرفة ILA}

sacred for "Osiris", the husband of their goddess "Isis", some calves that the Hellenes called (bull Apis). It was believed that "bull Apis" is the spirit of "Osiris" and the color of Egypt's fertilized land. Also, it was believed that there should be on the forehead of the calf a white mark that is closer to the shape of a triangle, on its back a drawing similar to a small eagle or hawk, and under its tongue a knot that looks like a scarab; the calf should have a double-haired tail, and sometimes it appeared on one of its sides a drawing similar to a crescent $^{(11)}$.

Priests and parsons determined these features to identify "bull Apis" because these are the features that emphasize the repetition of miraculous birth without breeding (by the spirit, as Isis returned Osiris to life by a breath). This miraculous birth had first happened in the story of Osiris who met the goddess Isis after his death got their son, god Horus. Horus was a new embodiment to the god father Osiris, as he became a father and a son in one hypostasis (12). This symbolizes eternity and resurrection, and it took the shape of a human being just to be able to die, and therefore, Man can be resurrected and be eternal like him... and this a satisfactory reason for the "son" to occupy the place that we have mentioned. The spirit of Osiris could take over the animal that symbolizes it, and it is known as Apis. People considered such an animal supernatural as if 


\section{الجمعية المصرية للقر اعة والمعرفة عضو الجمعية الدولية للمعرفة ILA}

it was a spiritual and not a material animal.

Plutarchus says: "The bull Apis is born from a cow that is not bred by an earth calf, but is bred by a moon ray... The bull Apis is born form a cow that a fertile ray of the moon rays breeds while it is ready for pregnancy" (13). Aelianos narrates that a ray fell down form the sky on a cow was ready for pregnancy, and it gave birth to the bull Apis, that the Greek call Epaphos and for them, its mother is called IO ${ }^{(14)}$ Speaking about the signs that decorate Apis, Plinius says: "The first thing that distinguishes bull Apis is a crescent shaped white spot on its right side"."). Plutarchus here mentions that the Egyptians believed in the fertility of the moon to the extent that they indicated the beginning of the spring by the appearance of the new moon of month Phamenouth (Bermhat= February-March), and they called its feast "The entrance of Osiris in the moon". This means that Osiris is fertilized as the moon, and it is he who fertilizes the cow, that is going to be the mother of Apis, with the moon ray. Egyptians concentrated Osiris's fertility power in the moon, and therefore, some parsons came to say that Isis is nothing but the moon because her statues figure her with two horns crowning her head; those horns are nothing but an imitation of the figure of the god of the moon..."Eudoxos emphasized that Isis is the goddess whom people consulted regarding their sexual life; people are always 


\section{الجمعية المصرية للقر اعة والمعرفة عضو الجمعية الدولية للمعرفة}

communing with the moon concerning their love affairs" (16).

This is emphasized by the drawings for the moon orbits and phases that were found on the luxurious Sarcophagi for bull Apis (17), and it seems that the legend has mixed Osiris with the Moon god "Djebauti" and attributed each one's traits to the other in exchange (18). The surnames of the Moon god became that of Osiris: the knower, the experienced in knowledge, the master of magic, the inventor of writing, and the legislator. The most important surname that this study is deeply concerned with was "the master of foreign countries"; it is an old name that used to refer to the moon as a god for deserts and Bedouins, and therefore, people considered him always a god for the Semitic Bedouins who inhabited Sinai and the Syrian Valley ${ }^{(19)}$. Osiris, as a moon, became a "master of foreign countries" and got closer to the Semitic from an Egyptian point of view. For that reason, we find that the month referred to in Greek as "Phamenouth" is the same that the Egyptians called "Djebauti" that was later contracted to "Thoth"; it is the month of the moon that is related to land fertility and the beginning of the spring.

Plutarchus (20) sees that the Egyptians never allowed the slaughtering of female cows because they are sacred to the goddess Isis; something that goes with the economic need for the female cows and the necessity for keeping them because they are the 


\section{الجمعية المصرية للقر اعة والمعرفة عضو الجمعية الدولية للمعرفة ILA}

productive factory for newborns. Isis is what Greek called "IO", the daughter of "Inakhos", and the Greek used to figure her in the shape of a woman, decorating her head with the two horns of a cow ${ }^{(21)}$.

There are clear references in the translations of the Armenian papyrus of the Jewish military community that lived in Aswan in Egypt at Elephantine in the fifth century B.C. that the Jews, who separated from their people and lived there where they did not know about the development that their religion had undergone after they moved from Egypt to Palestine, kept for us an old stage of the Jewish religion. It was found that in this community, "Yahweh", the known Jewish god was worshipped, but beside him was worshipped his wife, the goddess "the females of Yahweh", "the female Yahweh" or "the feminine of Yohoo", and she was called "the queen of the sky" (22). This accords clearly with calling Isis "IO" which is "Yahweh" without any linguistic problems ${ }^{(23)}$. Reading the Old Testament, we get to know that when Moses wanted to get out with enslaved Israelis from Egypt, he brought an evidence before the Pharaoh implying that their religion obliges them to slaughter an immolation for God in a certain day, and that this immolation, in Egypt, is forbidden to be slaughtered. Therefore, the Israelis need to get out of the capital of the king to the desert to hold their feast. Here, Pharaoh answered saying, 


\section{الجمعية المصرية للقر اعة والمعرفة عضو الجمعية الدولية للمعرفة}

Go and slaughter for your God in this land, Moses answers, we cannot do this because we are slaughtering the Egyptians' squalor for our God. If we slaughtered the Egyptians' squalor in front of their eyes, would not they throw us with stones?. We will travel for three days and slaughter for our God as Heorderedus ${ }^{(24)}$.

This was the premise or the moment of exit from the Capital; walking for three days to slaughter an immolation that is forbidden to be slaughtered for the Egyptians just to prevent riots and unrest. However, this was their way to escape from Egypt after they are far enough to be safe from the pursuit when it starts. But after that, we do not find any details for any slaughtering, except for the slaughtering of sheep at their doorsteps in Egypt at the night of the exit, and this was not the meant slaughtering. Also, we do not have any story for the slaughtering of any other animal in the course of the exit, except for the story of worshiping the golden calf, and we do not find any reference to about slaughtering in Sinai except for the legislation of division; something that does not have any relation to the worshiping principles for animal offerings ${ }^{(25)}$.

Here comes the story in the Holy Koran to fill in the missing gap, when God, to whom be ascribed all perfection and majesty, orders Moses .....

Greek historian Plutarchus mentioned that the Egyptians 


\section{الجمعية المصرية للقر اعة و المعرفة عضو الجمعية الدولية للمعرفة ILA}

allowed the slaughtering of yellow bulls because they are alluring and red i.e. the color of the god of evil "Set" (26) Diodorus, the Sicilian, then tells us that the slaughtering of yellow or red bulls was allowed in the Osirius cult ${ }^{(27)}$. Then, why was Moses afraid form the Egyptians when he decided to slaughter a yellow animal offering for gods? Maybe, the secret beyond this was that the immolation was not an bull, but a female cow, and this was considered, according to the ancient Egyptian legend, a slaughtering of Isis, the divine enemy for god "Set" (28). This opinion is supported by a story told by a historian who was contemporary with it. The story tells that the people of "Maria' and "Apis', two cities which lied at the borders of western Egypt, sent to the parsons of "Amon" saying that they are not Egyptians, but Libyans, and that they are asking to be allowed to eat the meat of cows. However, the answer came from the inspiration of "Amon" temple in Siwa that their request is strictly rejected, something that refers to the strict prohibition of slaughtering female cows ${ }^{(29)}$. The Egyptians believed that the color of the Egyptian god of evil is red, so they allotted for the offerings those in their cattle that have a pure yellow color. They believed that Osiris was brown, so black color was sacred for them "(30).

For the Israelis, yellow was of special importance, so they made the bull, that they apostate to, form gold, and not from any other 


\section{الجمعية المصرية للقر اعة والمعرفة عضو الجمعية الدولية للمعرفة ILA}

unoriginal metal. This was a sign that they have deep faith concerning the tradition they used to follow in Egypt, worshiping their god "Set" that was represented by yellow cows that did not have any other color, and that they were strongly attached to its pure yellow symbol, and consent be to Mighty Allah when He says, "And the people of Musa (Moses) made in his absence, out of their ornaments, The image of a bull (for worship). It had a sound (as if it was mooing)" (31).

In this case, "Stroweet", the province attributed to god "Set", which does not exist at all in the Egyptian tables for the provinces in Ancient Egypt, was the area of power for the god of deserts ${ }^{(32)}$. This province must be Sinai. So, it could be said that Sinai is what is known as the province of "Stroweet", in attribution to god "Set", in the works of classical historians. Here, we have to note that "Stroweet" is the linguistic (?) for the Egyptian word "Dosreet" or "Doshreet" that signifies wide deserts ${ }^{(33)}$.

Special sources in Semitisms tell us that Sinai got its name in attribution to the god of the moon, which is pronounced "Sin" in Semitic. Horned bull were connected with the god of the moon especially when it is a crescent, after the ancient man had associated between the two horns of horned bull and the moon, as he considered the moon an bull, a goat or a heavenly sheep ${ }^{(34)}$. God 


\section{الجمعية المصرية للقر اعة و المعرفة عضو الجمعية الدولية للمعرفة ILA}

"Set" was associated to the god of the moon, the master of deserts and nomads. This preponderates that the name of "Sin for the moon" had originally come form the singular, the " $S$ " in "Set". What concerns us here is that Sinai is a name attributed to the Egyptian god "Set", and the bull here is a moon manifestation for the Bedouin god of Sinai. Thus, Sinai and "Stroweet", though different in pronunciation, are attributed to the Egyptian god "Set" (35). to whom Egyptians made advances to approach in fear of his desert evilness. This comes clear in their practices of presenting him offerings of bull and red or alluring cows that were of pure color. If they had found just one hair of different color, they would have considered the offering unsuitable to sacrifice. Consequently, the offering for "Set" was an bull or a bright yellow cow ${ }^{(36)}$.

The most prominent stories that reached us about the Egyptian god of evil, "Set", is the story that came within the Greek Plutarchus's telling of the legend about "Osiris", the god of good, and his fight with "Set", the god of evil. After the death of "Osiris", the fight continues under the leadership of "Horus", Osiris's son in revenge for his father from his evil uncle. The fight ends in the defeat of evil "Set" by "Horus". Plutarchus says, After Horus had defeated him...Set ran away riding a donkey. His journey took seven days on the back of the donkey...because Set used a donkey, and 


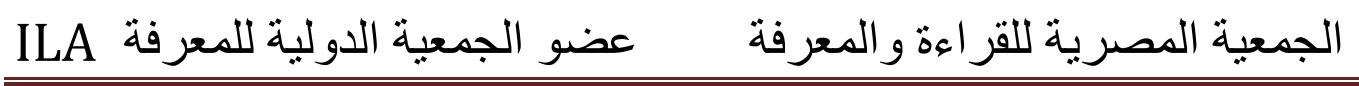

because of the stupidity of donkeys and red color, donkeys were attributed to Typhon, (Typhon is the Greek name for god Set). This was a reason for the Egyptians' hatred for donkeys in their creed. For this reason, they called Ochus, the cruelest and evilest Persian king, (Artaxerxes, III) a donkey?. Because of his cruelty and tyranny. He then answered the Egyptians back saying: this donkey will celebrate eating your calf. Concerning those people who say that Set's journey of escape had taken seven days on the back of a donkey, that he was saved and that he became the father of Hierosolymos and Judaeos, they aimed at getting the Israeli traditions into the Egyptian legend (37).... The fact, then, is that after the Egyptians had known the people of Israel, they linked them with the paternal brothers of the father Set, the god of evil and devil, the enemy god in their creed.... The people of Israel in Egypt became the sons of Set, whom the Greeks call Typhon, i.e. they descend from an evil origin. The Egyptians made him ...a symbol for all harmful animals and plants, salt sea and horrible accidents..Hierosolymos and Judaeos are the Hebrew fathers of the Jews.

Plutarchus repeats what supports what we have reached concerning one of the figure in which god Set is manifested in the shape of a donkey, and concerning the red color. The red color was a symbol of infertility as well as assign for Sinai and its inhabitants ${ }^{(38)}$. 


\section{الجمعية المصرية للقر اعة والمعرفة عضو الجمعية الدولية للمعرفة}

Thus... it came the sacrifice that Moses took as a premise for getting out of the Pharaoh's city to the desert in order not to provoke the feelings of the Egyptians, and the blond was a clear sign that refers to the Egyptian god "Set", but it was a female cow. Here comes the question: was the slaughtering of the cow, that symbolizes Isis, who was called "IO" or the female "Yahweh" and who was the divine enemy of god Set according to the legend, mere provoking for the feelings of the Egyptians? If it had been so, they would have slaughtered it inside the Egyptian city. So, why did they go out far from the Egyptians to slaughter it?.

We understand from Herodotus and other classic historians that the Egyptians, in their turn, were used to slaughter the female bright yellow spoilt cow, but just on a certain celebrating day, which is the day of celebrating the glorious Easter of martyr Osiris. However, we do not have any testimony from the Egyptian sources that states the secret beyond this strong contradiction between prohibiting the slaughtering of female cows and the slaughtering a yellow cow at the celebration of that religious day ${ }^{(39)}$.

In the reference mentioned in the Holy Koran in verse 88 in chapter "Taha" concerning the worshiping of the calf, the singular form in "This is your illah (god), and the illah of Musa (Moses)" is used, while the Old Testament the plural form in "Israel, these are 


\section{الجمعية المصرية للقر اعة والمعرفة عضو الجمعية الدولية للمعرفة ILA}

your gods who have got you from Egypt" (40) The verse shows that the meant god is the bull, and it mentions that this happened near the mountain that Moses had ascended to get instructions from his God, the mountain that we call the Mountain of Moses ${ }^{(41)}$. Researchers have interpreted the peoples of Israel worshipping of the bull saying that it was an apostasy to the worshipping of the bull that the Egyptians worshipped with the name "Apis". However, what is mentioned in the Holy Koran, then in the Old Testament is completely the opposite showing that the bull was an old god that the ascendants of the Hebrews were worshipping before prophets reached the message of the unity of God (Allah), because it is not acceptable that the gods or the god that got them out of the slavery of the Egyptians IS Egyptian, but it is logical that it is a Semitic god ${ }^{(42)}$.

Thus, when the people of Israel found themselves in Sinai, where the worshipping of the god "Sin", the Semitic god of the moon, pervaded, and when Moses was absent, they quickly fell back to worshipping this god that the Semitic groups, who used to inhabit Sinai long ago, worshipped. The evidence on the oldness of worshipping the Semitic god of the moon in Sinai is one of the early pharaohs, (Pharaoh Snefrou), the old king of the fourth pharaoh Dynasty (2538- 2561 B.C.), who figured himself wearing a crown with a crescent shape, symbolizing the god of the moon "Sin", when 


\section{ILA الجمعية المصرية للقر اعة والمعرفة عضو الجمعية الدولية للمعرفة}

he wanted to express his victory over the Semitic inhabitants of Sinai!" (34).

\section{Notes:}

(1) Valbelle . D., Le Sanctuaire d'Hathor, Maitresse de la Turquoise, Paris, 1996 ,pp. 36ff.

(r) أحمد فخرى، تاريخ شبه جزيرة سيناء منذ أقدم العصور حتى ظهور الإسلام- شبه جزيرة سيناء على مر العصور - موسو عة سيناء الهيئة العامة للكتاب، ب1911 ، ص. 85.

(3) This supposedly goes to the fact that some of mines workers in Serabit ElKhadim were of Asian Semitic origins, where it was proven that Egypt had relations with their countries since the twelfth family, ad that some of the inhabitants in the Syrian areas were working in Serabit El- Khadim. See:

$$
\text { احمد فخرى ، مرجع سابق ، ص ص. 1 • 1 - · 11. }
$$

(4) Hans Goedicke, The Exodus and the Crossing of the Sea, Biblical. archaeology review, Sep-Oct. 1981, vol. vii, no. 5, pp. 42 - 54. Cf; Valbelle . D., op. cit., pp. $36 \mathrm{ff}$.

(5) Petrie. F., Memphis I, London, 1980, pl. 28. In 1905, British archeologist Flenders Petrie found in Serabit El- Khadim near the mines in Sinai some writings inscribed in Turquoise on rocks; these writings are called now the "Proto-sinatic writings". It came clear that the Proto-sinatic is the oldest writing that uses the alphabet till now. Petrie found a discovery for this on some remains that had been built in the age of "Tohothmos III" during first half of the fifteenth century B.C. After Petrie's discovery, more Protosinatic writings were found after a Fenlandian mission had found in 1929. New writings, followed by the American Harvard University mission that discovered the same writings in other 


\section{الجمعية المصرية للقراعة والمعرفة عضو الجمعية الدولية للمعرفة ILA}

sites, till what has been found reached 25 texts. These texts are concerned with the works of excavating Turquoise in Sinai and sacrificing some offerings, that are called "obedience" to "Baallat Hathor" and "Baallat" is a Semitic surname that means the female of "Baal Hathor is an Egyptian goddess, something that refers to the Egyptian who Semitic mixing and combination in that area that lies in the west of in the west of Katherine Mountains, a sacred place, to which Moses directed with his followers when he got out of Egypt. See

$$
\text { أحمد فخرى، در اسات في تاريخ الثرق القديم، الانجلو المصرية، القاهرة 1984، ص. VY }
$$

(6) In a temple in Serabit El- Khadim , there were found neliafs were found neliafs that were

similar in their job to the Semitic monuments. Among them were twelve neliafs held along the passage leading to the temple. Flenders Petrie, who discovered them, sees that these monuments are a kind of memorial Reliefs established by their owners at the sacred places which they visit or go for pilgrimage to immortalize their visit to the place and to come closer to the gods of the place. This was a common habit for the Semitics. This kind of monuments was called "Beet-Eiel" in the Old Testament, as mentioned in 28: 10-19 in the creation book. Petrie observed that many of these neliafs in the temple of Serabit ElKhadim are surrounded by low fences. From this, he concluded that the Egyptians were influenced in that area by the Semitic habit of resurrecting gods in dreams, that they were practicing this habit in Serabit El- Khadim , and that this habit aimed at resurrecting goddess "Hat-Hor", the goddess of Turquoise, to guide them in their dreams to the sited of Turquoise in the bottom of rocks. See:

Petrie. F., Researches in Sinai, Mines and quarries department of Egypt, report on the mineral of Egypt, 1922, pp. 79-80. 


\section{الجمعية المصرية للقراعة والمعرفة عضو الجمعية الدولية للمعرفة ILA}

(7) Gardiner - Peet - Cérny ., The Inscriptions of Sinai , London 1955, vol. I, pl. 88 , No. 478.

$$
\text { علي عبد الو احد وافي، اليهودية و اليهود، دار نهضة مصر، القاهرة - بدون تاريخ ، ص. 61- } 63 .
$$

(8) Aly Abd-El-Wahed, mentions the story of the cow in the Old Testament. In a kind of primitive anatomy, he says, "If the corpse of a dead person had been found in the open or in the middle of a field, and it had not been acknowledged, the Jewish masters should have measured the distance between the corpse and the near-by villages. When the nearest place was determined, they were to ask the leaders of this village to bring a cow that had not been used in work yet, and to slaughter it in a water stream. The people in the mage had to wash their hands in the water swearing that they did not kill. neither did they see the dead person. In that way, they would not bear the sin of killing him see:

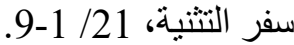

(9) Plutarchus, De Iside et Osiride, Mortalia V., edited with an introduction. Trans, and commented by J. Gwyn Griffiths, Uni. Of Wales Press, 1970, No. 74. (10) Ibid , 52.

(11) Herodotus , II . 38.

(12) "He brings out the living from the dead, and brings out he dad from the living”. Chapter “Al-Rum”, verse (19).

(13) Plutarchus, op. cit., 43.

(14) Herodotus, II, 28 and 38.

(15) Plinius, Naturalis Historia, viii, 184.

(16) Plutarchus, 52 - 372 D.

$$
\text { (17) سليم حسن، مصر القديمة، } 16 \text { جزءًا، القاهرة } 83 \text { - } 83 \text { - 1960م، ج 4، ص. } 196 .
$$




\section{الجمعية المصرية للقراعة و المعرفة عضو الجمعية الدولية للمعرفة ILA}

(18) Strabo ( xvii , 40 ) observed that in the city of Kinopolis i.e. the city of the dog, god "Anubis", the god of dead dogs, was worshipped, and that there was held then a banquet for the dogs. He also observed that the people of Babylon, in his time, used to glorify and extol the Cyno- Cephalus = the monkey with a dogshaped head. Plutarchus, op-cit., 62 mentions that the dog of the Bebon, "Djebauti", the god of wisdom, was associated with "Set", the god of Bedouins as he went out of his head. He says, "it is called Tophoon- Set- Bebon and Smu. Above all, they call iron Typhon's bones ; thon as Manithon mentions".

(19) ياروسلاف تثيرني ، الديانة المصرية القديمة ، نرجمة أحمد قدري، هينة الآثار المصرية، القاهرة A. - V9 ص (191V

Says that set was worshipped as 'Baal' by the Semitics. He was the god of war for the Egyptians and the Semitics. He was the god of good for the Semitics, and the god of evil for the Egyptians. He is Baal Safoon or Baal Saban. Changing the letter "s" to "t", Safoon in Greek becomes "Typhon", the god of evil and epidemics. This means that the Greek god is not Greek, but an eastern god coming form Sinai .

(20) Plutarchus, 22 - 359 B , and $31-362$.

(21) Herodotus, II, 28 .

(22) Grelot. p.trad., Documents araméens d'Egypt, littératures ancienne du Proche - Orient, 5, Paris, 1972, no. 87.

و انظر أيضًا: كمال الصليبي، التوراة جاءت من جزيرة العرب، ترجمة عفيف الرزاز، مؤسسة الأبحاث العلية، بيروت، بدون تاريخ، ص.

(23) Lods. A., Israel from its beginnings to the middle of Eight Century, London, 1963, pp. $321-322$.

(24) The Exodus Book, 8/25-27. 


$$
\text { (25) علي عبد الواحد وافي، المرجع السابق، ص. } 60 \text { وما بعدها. }
$$

(26) Plutarchus, $31-362$.

(27) Diodorus, 1, 88, 4-5.

(28) Ibid, I, 88, 4 - 5.

(29) Herodotus, II. 28.

(30) Ibid, II., 28.

(31) Chapter Al-A'raf, verse (148). Abd-AL-Sabour Shaheen says commenting on this verse, The story started with Moses ascending the mountain leaving his brother" Haroon " to be his successor in his people. Then, one man who belongs to the people of Israel came and collected all the gold and ornaments people have gotten with them from Egypt, put it in a hole ( pit ) and lit fire. After that, he shaped it in the image of a calf who made a sound as if it was mooing. He, then, tells the people of Israel : This is your God and the God of Moses to well. This was a calf that is similar to Abis, the calf that the Egyptians worshipped. It seems that this man Al-Sameri, knew about tricks, and sounds (voices); something that made the people of Israel interested him; made them admire his invention and hurry to worship this new god. See:

$$
\begin{aligned}
& \text { الأستاذ إصلاح عبد السلام الرفاعي، قصة الدين و النبوة في مصر قبل الإسلام، الزهر اء للإعلام العرب، } \\
& \text { القاهرة، 1996، ص. } 186 . \\
& \text { (32) سليم حسن، مصر القديمة، مرجع سابق، ج4، ص ص. } 65 \text { - } 66 .
\end{aligned}
$$

Says that Mr. Jankor proved that god Set was the local god for the city strt i.e sethroite in the Greek era. This city lies in the Eastern North to the Delta, as Jankor believes. Set was the local worshipped god for this region in which the Heksos built the fortifications in their great capital that they considered a point 


\section{الجمعية المصرية للقر اعة والمعرفة عضو الجمعية الدولية للمعرفة ILA}

of connection among the parts of their enormous country and that included Egypt , Palestine and Syria . It seems that the Heksos were a mixture of different races ... We know that both gods, Baal and Tshoop were united in the god Set.

(33) Hayes. W. C., Egypt from the death of Ammenemes II , p. 17.

محمد بيومي مهران، دراسة حول الديانة المصرية القديمة، الأسكندرية 9V^ا، ص • ب وهامش رقم

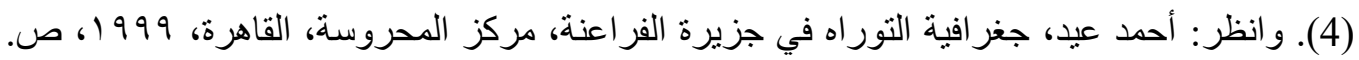
.rVI

(34) Gardiner, op. cit., Vol. I, pl. 2, No. 5.

$$
\text { (35) سليم حسن، مصر القديمة، مرجع سابق، ج4، ص ص. } 65 \text { - } 66 .
$$

(36) About " donkey " Plutarchus ; op.cit., 31. emphasizes the relationship between the word " Ahmar ", " Hemar " the color red The people of Osiris and Lycopolis prohibited the use of horns and trumpets because the make sounds similar to e, they believed that the donkey is a dirty animal. Therefore, this of the donkey goar. Its offerings were bulls, yellowish red, provided that they are pure. They have to be bright yellow that please the beholders.

(37) Ibid, 31 .

(38) يقول ياروسلاف تشيرني ، الديانة المصرية القديمة، مرجع سابق، ص. 161 .

"The animals symbol for the worshipped god Setekh represented an animal that looks like a donkey

و وانظر أدولف إرمان، ديانة مصر القديمة، نشأتها وتطورها ونهايتها" في أربعة آلاف سنة، ترجمة عبد

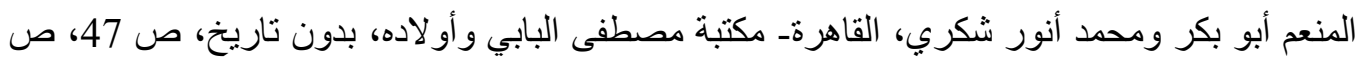

(39) Herodotus , II.132. 


\section{الجمعية المصرية للقر اعة والمعرفة عضو الجمعية الدولية للمعرفة ILA}

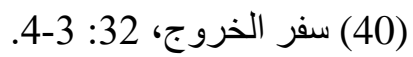

(41) Hans Goedicke, op. cit. vol. vii , pp. 42 - 54.

$$
\text { (42) سليم حسن، مصر القديمة، مرجع سابق، ج ז، ص. } 304 .
$$

Say's that the bull that the people of Israel worshipped was the bull, or the bull that symbolizes the Semitic Moon, which was worshipped in Sinai with the name " Sin", a very old god. God in the Arabic Island that was worshipped in the shape of a bull or an ox in almost all its regions. It seems that this was the common god worshipped by the Semitic tribes that inhabited the Semitic countries. These Semitic people symbolize the god " $\sin "$ in the shape of a bull or an ox because of the similarity between the crescent shape of the moon and the crescent shape of the horn of the bull or the ox .

(43) Petrie. F., Researchers in Sinai, op. cit., p. 43.

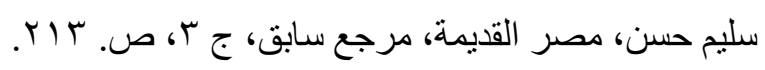

